\title{
A new prognostic index in patients with hormone receptor-positive and HER2-negative breast cancer
}

\author{
Nowy wskaźnik prognostyczny u pacjentek z rakiem piersi i ekspresją receptorów hormonalnych \\ oraz brakiem ekspresji HER2
}

\author{
'Department of Medical Oncology, Ankara Dışkapı YIIdrım Beyazıt Training and Research Hospital, Ankara, Turkey \\ ${ }^{2}$ Department of Medical Oncology, Zonguldak Bülent Ecevit Medical School, Zonguldak, Turkey \\ Correspondence: Hayriye Şahinli, Şehit Ömer Halisdemir Street, No: 22, Altındağ, Ankara, Turkey, tel.: 05536934969, e-mail: dr.hayriye@hotmail.com, ORCID ID: http://orcid.org/0000-0002-1561-9346
}

Abstract Aim: Breast cancer is a heterogeneous disease. This study investigated the pretreatment prognostic significance of a new inflammatory index in hormone receptor positive (HR+) and human epidermal growth factor negative (HER2-) breast cancer patients. Methods: We retrospectively analyzed 80 patients diagnosed with HR+ and HER2- breast cancer between January 2014 and December 2018. We calculated prognostic inflammatory index (PII) = mean platelet volume $(\mathrm{MPV}) \times$ neutrophil/lymphocyte. PII cut off was the best-predicted value by receiver operating characteristic (ROC) curve analysis. We used the Kaplan-Meier method to determine disease-free survival (DFS). We used the log-rank test to compare the DFS rates between the two patient groups. We performed a multivariate analysis by performing Cox regression analysis with prognostic factors defined in univariate analysis. Results: The median follow-up period was 38 (19-66) months. The 5-year survival was $91.3 \%$. The 5-year DFS was $87.9 \%$. The optimal cut-off value of MPV $\times$ neutrophil/lymphocyte ratio was determined as 22 by ROC curve analysis [area under the curve, AUC 735, HR \% CI (confidence interval) 0.561-0.909, sensitivity 72.7\%, specificity 70.4\%]. The number of patients with $\mathrm{PII} \leq 22$ was 60 , and the number of patients with PII $>22$ was 32 . DFS was worse in the high PII group than in the low PII group $(p=0.001)$. Multivariate analysis revealed PII as an independent prognostic factor $(p=0.016)$. Discussion: In this study, we detected elevated MPV $\times$ neutrophil/lymphocyte ratio as an independent poor prognostic factor in operated HR+ and HER2- breast cancer patients. Prospective studies are needed to determine the prognostic significance of this index.

Keywords: breast cancer, estrogen receptor, progesterone receptor

Streszczenie Cel: Rak piersi jest chorobą heterogenną pod względem histologicznym i biologicznym. W badaniu dokonano analizy znaczenia prognostycznego nowego wskaźnika stanu zapalnego przed rozpoczęciem leczenia u pacjentek z rakiem piersi i obecnością receptorów hormonalnych (HR+) oraz brakiem ekspresji receptora czynnika wzrostu naskórka (HER2-). Metoda: Analizą retrospektywną objęto 80 pacjentek, u których w okresie od stycznia 2014 do grudnia 2018 roku rozpoznano raka piersi HR+/HER2-. Obliczono prognostyczny wskaźnik stanu zapalnego (prognostic inflammatory index, PII): PII = średnia objętość płytek krwi (mean platelet volume, $\mathrm{MPV}) \times$ stosunek neutrofili do limfocytów. Punkt odcięcia wskaźnika PII był najlepszą wartością przewidywaną w analizie pola pod krzywą ROC (receiver operating characteristic). W celu określenia czasu wolnego od choroby (disease-free survival, DFS) zastosowano metodę Kaplana-Meiera, a do porównania wskaźnika DFS w dwóch grupach pacjentek - test log-rank. Przeprowadzono analizę wieloczynnikową metodą regresji Coxa z czynnikami prognostycznymi określonymi w analizie jednoczynnikowej. Wyniki: Mediana okresu obserwacji wyniosła 38 (19-66) miesięcy. Wskaźnik pięcioletniego przeżycia wynosił 91,3\%, a pięcioletniego przeżycia wolnego od choroby - 87,9\%. Optymalna wartość odcięcia dla wskaźnika PII (MPV × stosunek neutrofili do limfocytów) obliczona na podstawie analizy krzywej ROC wyniosła 22 [pole pod krzywą, AUC 735, HR \% CI (przedział ufności) 0,561-0,909, czułość 72,7\%, specyficzność 70,4\%]. PII $\leq 22$ i >22 stwierdzono odpowiednio u 60 i 32 pacjentek. W grupie z wysoką wartością wskaźnika PII odnotowano krótszy czas przeżycia bez choroby w porównaniu z grupą z niską wartością tego wskaźnika $(p=0,001)$. Na podstawie analizy wieloczynnikowej stwierdzono, że wskaźnik PII jest niezależnym czynnikiem prognostycznym $(p=0,016)$. Omówienie: W niniejszym badaniu stwierdzono, że podwyższona wartość PII (MPV $\times$ stosunek neutrofili do limfocytów) stanowi niezależny czynnik złego rokowania u leczonych operacyjnie pacjentek z rakiem piersi HR+/HER-. Konieczne jest przeprowadzenie prospektywnych badań w celu ustalenia znaczenia prognostycznego tego wskaźnika. 


\section{INTRODUCTION}

$\mathrm{D}$ espite all advances in treatment, breast cancer is still the most important cause of cancer-related deaths in women. Breast cancer is divided into three main histological types [estrogen receptor (ER) status, progesterone receptor (PR) status, and human epidermal growth factor (HER2) overexpression], depending on the presence and absence of molecular markers. Hormone receptor-positive breast cancer accounts for $70 \%$ of all breast cancers ${ }^{(1)}$. It is estimated that 5 -year survival is $91 \%$ in this group ${ }^{(2)}$. Prognostic factors in breast cancer depend on lymph node metastasis status, tumor size, tumor grade, vascular invasion, ER status, PR status, and HER2 overexpression status ${ }^{(3)}$.

Tumor microenvironment, inflammation, and immune response have been shown to play an essential role in tumor progression and prognosis ${ }^{(4)}$. Biomarkers such as neutrophil, lymphocyte, platelet, mean platelet volume, platelet neutrophil ratio (PLR) and neutrophil-lymphocyte ratio (NLR) are determinants of inflammation ${ }^{(5)}$. These indicators are prognostic factors in many solid tumors ${ }^{(6-9)}$.

It has been shown that many hormone receptor positive (HR+) breast cancer patients receive unnecessary chemotherapy and a relatively low proportion of these patients benefit from chemotherapy. Important prognostic markers are needed to select the appropriate treatment. Reliable molecular diagnostic tests, such as MammaPrint and Oncotype DX tests, are available. However, they cannot be used due to the high costs and limited availability in many countries. Affordable and easily accessible prognostic markers are needed to determine the appropriate treatment for $\mathrm{HR}+$ breast cancer patients.

In this study, we investigated the prognostic significance of a new prognostic index in hormone receptor positive and human epidermal growth factor negative (HER2-) breast cancer patients.

\section{MATERIALS AND METHODS}

We retrospectively analyzed 80 patients diagnosed with HR+ and HER2- breast cancer between January 2014 and December 2018. We obtained patient data from electronic records and patient files. We excluded patients with metastatic breast cancer, patients with negative hormone receptors, and patients with active inflammatory disease. We administered adjuvant therapy according to NCCN (National Comprehensive Cancer Network) Guidelines.

We obtained hematological parameters from electronic records before any treatment of patients who underwent surgery. We defined the prognostic inflammatory index (PII) $=\mathrm{MPV} \times$ neutrophil/lymphocyte ratio.

\section{Statistical analysis}

Statistical analysis was performed using SPSS version 20 (SPSS Inc., Chicago, IL). We analyzed the relationship between clinicopathological characteristics using

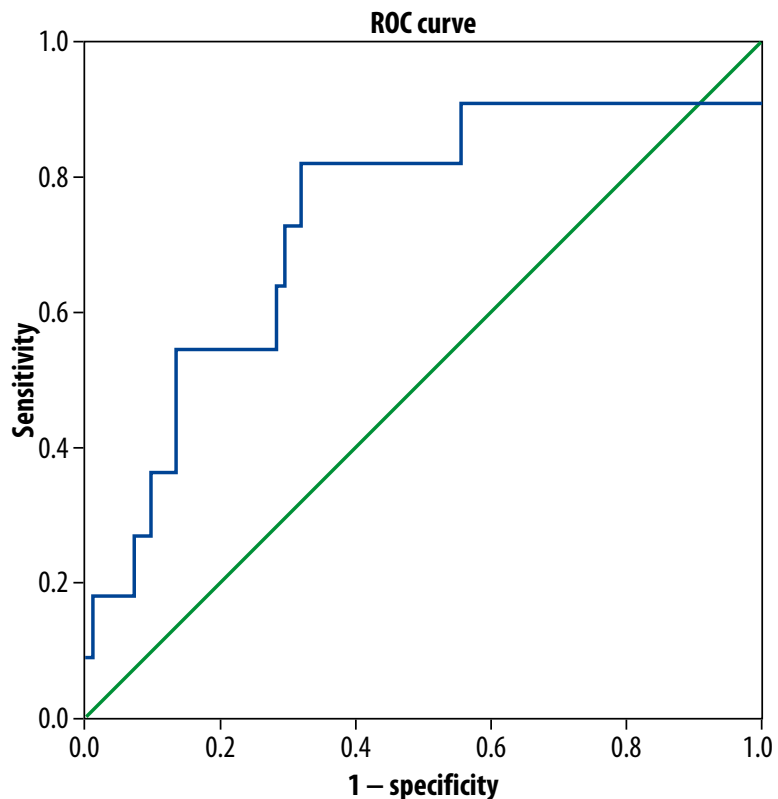

Fig. 1. ROC curve of PII for DFS prediction

a chi-square test. We determined the survival curve by Kaplan-Meier analysis and compared it using the log-rank test. We performed a multivariate analysis with the Cox regression model with significant factors in univariate analysis. A $p<0.05$ was considered statistically significant. The optimal cut-off value of PII and neutrophil-lymphocyte ratio for recurrence was determined by the receiver operating characteristic curve. The median value was taken as the cut off value for PLR.

Overall survival was defined as the time from diagnosis to death or last visit. Disease-free survival (DFS) was defined as the time from diagnosis to the date of relapse.

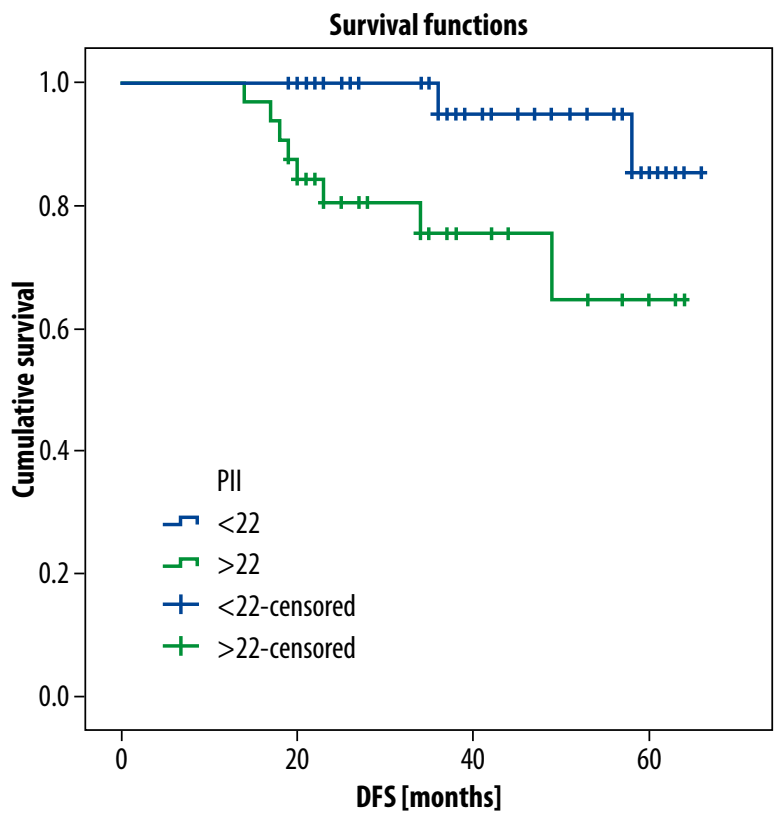

Fig. 2. Kaplan-Meier survival curves of DFS according to PII 


\begin{tabular}{|c|c|c|c|}
\hline & $\begin{array}{c}\mathrm{PII} \leq 22 \\
n(\%)\end{array}$ & $\begin{array}{c}\text { PII >22 } \\
n(\%)\end{array}$ & $p$ value \\
\hline $\begin{array}{l}\text { Age [years]: } \\
\cdot<60 \\
\cdot>60\end{array}$ & $\begin{array}{l}39(65) \\
21(35) \\
\end{array}$ & $\begin{array}{l}21(65.6) \\
11(34.4) \\
\end{array}$ & 0.952 \\
\hline $\begin{array}{l}\text { Tumor size: } \\
\cdot \leq 2 \mathrm{~cm} \\
\cdot>2 \mathrm{~cm}\end{array}$ & $\begin{array}{l}22(36.7) \\
38(63.3)\end{array}$ & $\begin{array}{l}14(43.8) \\
18(56.2)\end{array}$ & 0.507 \\
\hline $\begin{array}{l}\text { Grade: } \\
\cdot 1,2 \\
\cdot 3\end{array}$ & $\begin{array}{c}51(85) \\
9(15)\end{array}$ & $\begin{array}{l}22(68.8) \\
10(31.2)\end{array}$ & 0.067 \\
\hline $\begin{array}{l}\text { Lymph node metastasis: } \\
\text { - no } \\
\text { - yes }\end{array}$ & $\begin{array}{l}35(58.3) \\
25(41.7)\end{array}$ & $\begin{array}{l}22(68.8) \\
10(31.2)\end{array}$ & 0.293 \\
\hline \begin{tabular}{|l|} 
PLR: \\
$\cdot<134$ \\
$\cdot>134$
\end{tabular} & $\begin{array}{l}36(60) \\
24(40)\end{array}$ & $\begin{array}{l}10(31.2) \\
22(68.8)\end{array}$ & 0.009 \\
\hline \begin{tabular}{|l|} 
NLR: \\
$\cdot<2.49$ \\
$\cdot>2.49$
\end{tabular} & $\begin{array}{c}53(88.3) \\
7(11.7)\end{array}$ & $\begin{array}{c}3(9.4) \\
29(90.6)\end{array}$ & $<0.001$ \\
\hline
\end{tabular}

Tab. 1. Relationships between prognostic inflammatory index and clinicopathological factors

\begin{tabular}{|c|c|c|c|}
\hline & \multirow{2}{*}{$\begin{array}{c}\text { Univariate } \\
p \text { value }\end{array}$} & \multicolumn{2}{|c|}{ Multivariate } \\
\hline & & HR (95\% Cl) & $p$ value \\
\hline $\begin{array}{l}\text { Age [years]: } \\
\bullet<60 \\
\cdot>60\end{array}$ & 0.819 & & \\
\hline $\begin{array}{l}\text { Grade: } \\
\cdot 1,2 / 3\end{array}$ & 0.574 & & \\
\hline $\begin{array}{l}\text { Lymph node metastasis: } \\
\text { - no } \\
\text { - yes }\end{array}$ & 0.169 & & \\
\hline $\begin{array}{l}\text { Tumor size: } \\
\cdot \leq 2 \mathrm{~cm} \\
\cdot>2 \mathrm{~cm}\end{array}$ & 0.529 & & \\
\hline $\begin{array}{l}\text { NLR: } \\
\cdot<2.49 \\
\cdot>2.49\end{array}$ & 0.048 & $\begin{array}{c}0.592 \\
(0.104-3.257)\end{array}$ & 0.554 \\
\hline \begin{tabular}{|l|l} 
PLR: \\
$\bullet<134$ \\
$\bullet>134$ \\
\end{tabular} & 0.404 & & \\
\hline $\begin{array}{l}\text { Pll: } \\
\cdot \leq 22 \\
\cdot>22\end{array}$ & 0.001 & $\begin{array}{c}0.099 \\
(0.015-0.649)\end{array}$ & 0.016 \\
\hline
\end{tabular}

CI - confidence interval; NLR - neutrophil to lymphocyte ratio; PLR - platelet to lymphocyte ratio; PII - prognostic inflammatory index.

Tab. 2. Univariate and multivariate analyses of factors for the prediction of DFS

\section{RESULTS}

The median age was $56(38-86)$ years. The median followup period was 38 (19-66) months. The 5-year survival was 91.3\%. The 5-year DFS was $87.9 \%$. Recurrence occurred in $11(12 \%)$ patients during follow-up.

The optimal cut-off value was taken as 22 for DFS by PII receiver operating characteristic (ROC) analysis (AUC 735, HR 0.561-0.909, sensitivity $72.7 \%$, specificity $70.4 \%$ ) (Fig. 1).
The optimal cut off value for PLR was taken as the median value of 134 . The optimal cut-off value for the NLR by ROC analysis was 2.49 (AUC 673, HR 0.491-0.885, sensitivity $63.6 \%$, specificity $64.2 \%$ ). The number of patients with PII $\leq 22$ was 60 , and the number of patients with PII $>22$ was 32 . The relationships between prognostic inflammatory index and clinicopathological factors are summarized in Tab. 1 There was a significant relationship between high PII and PLR $(p=0.009)$ and NLR $(p<0.001)$. However, there was no significant relationship between PII and age ( $p=0.952)$, tumor diameter $(p=0.507)$, lymph node involvement $(p=0.293)$ and histological grade $(p=0.067)$ (Tab. 1$)$. DFS was found to be worse in the high PII group than in the low PII group $(p=0.001)$. At 12 months, the DFS of patients with low PII was $100 \%$, while the DFS of patients with high PII was $80.3 \%$. DFS of patients with low PII at 24 months was $94.9 \%$, whereas DFS of patients with high PII was $75.4 \%$. The DFS of patients with high PII was $64.6 \%$ at 36 months, while the DFS of patients with low PII was $94.9 \%$.

The prognostic effect of clinicopathological variables on DFS is summarized in Tab. 2. Using a univariate analysis, we found a significant correlation between NLR $(p=0.048)$ and prognostic inflammatory index $(p=0.001)$ with DFS. However, age, histological grade, lymph node involvement, and tumor diameter were not significantly associated with DFS. When the multivariate analysis was performed using significant findings in univariate analysis, we found that PII was an independent prognostic factor $(p=0.016)$.

\section{DISCUSSION}

In recent years, there has been an increase in the number of studies showing the importance of systemic inflammation markers in cancer prognosis. In this study, we demonstrated that MPV $\times$ neutrophil/lymphocyte ratio was a poor prognostic factor for DFS in patients with HER2- and HR+ localized breast cancer. For this index, the cut-off value was taken as 22 with $72.7 \%$ sensitivity and $70.4 \%$ specificity by ROC-curve analysis.

Platelets play a role in tumor growth and metastasis. Platelets release various growth factors and cytokines that support tumor growth, invasion, and metastasis ${ }^{(10)}$. Studies have shown that increased platelet count in patients with breast cancer is associated with poor prognosis ${ }^{(11)}$. Large platelets are more metabolically and enzymatically active than small platelets. The MPV level is a marker of platelet activation and function. Elevated MPV levels are also associated with platelet aggregation, thromboxane synthesis, and $\beta$-thromboglobulin release, which are other markers of platelet activation $^{(12)}$. Studies have shown that platelet indicators have essential roles in disease activity in cancer ${ }^{(13,14)}$. Elevated MPV levels are a poor prognostic factor in many types of cancer such as hepatocellular cancer, colorectal carcinoma, and gastric cancer ${ }^{(15,16)}$. In patients with invasive breast cancer, pretreatment MPV levels were found to be significantly higher than in healthy controls ${ }^{(17)}$. 
Studies have shown that the microenvironment of the tumor plays an essential role in cancer progression ${ }^{(18)}$. The tumor microenvironment has an impact on treatment response and overall outcomes of patients. Neutrophils, which are crucial factors in the tumor microenvironment, have an essential regulatory role in tumor progression ${ }^{(19)}$. Neutrophils are cells responsible for host defense and immune modulation. Research has shown that neutrophils play a critical role in chronic inflammatory diseases, including cancer ${ }^{(20)}$. Once neutrophils are integrated into the cancer cell, they release some cytokines, such as transforming growth factor-beta and vascular endothelial growth factor, inducing cancer cell proliferation, infiltration and metastasis. Lymphocytes are known to play a crucial role in cancer suppression by inducing cytotoxic cell death. High tumor infiltrated lymphocytes have been shown to play an essential role in the prognosis of many cancers such as breast cancer, gastric cancer and lung cancer ${ }^{(21-23)}$.

The limitations of our study were as follows: the number of patients was low due to its single-center nature, it was a retrospective study and the follow-up period was short.

\section{Conflict of interest}

The authors have no conflicts of interest to declare.

\section{Ethics statement}

This retrospective observational study was approved by the Ethics Committee of the Ankara Dışkapı Yıldırım Beyazıt Training and Research Hospital.

\section{References}

1. Waks AG, Winer EP: Breast cancer treatment: a review. JAMA 2019; 321: 288-300.

2. Nasrazadani A, Thomas RA, Oesterreich S et al.: Precision medicine in hormone receptor-positive breast cancer. Front Oncol 2018; 8: 144.

3. Bundred NJ: Prognostic and predictive factors in breast cancer. Cancer Treat Rev 2001; 27: 137-142.

4. Hanahan D, Weinberg RA: Hallmarks of cancer: the next generation. Cell 2011; 144: 646-674.

5. Hutterer GC, Stoeckigt C, Stojakovic T et al.: Low preoperative lymphocyte-monocyte ratio (LMR) represents a potentially poor prognostic factor in nonmetastatic clear cell renal cell carcinoma. Urol Oncol 2014; 32: 1041-1048.
6. Li MX, Liu XM, Zhang XF et al.: Prognostic role of neutrophilto-lymphocyte ratio in colorectal cancer: a systematic review and meta-analysis. Int J Cancer 2014; 134: 2403-2413.

7. Xiao WK, Chen D, Li SQ et al.: Prognostic significance of neutrophil-lymphocyte ratio in hepatocellular carcinoma: a metaanalysis. BMC Cancer 2014; 14: 117.

8. Chen J, Deng Q, Pan Y et al.: Prognostic value of neutrophil-tolymphocyte ratio in breast cancer. FEBS Open Bio 2015; 5: 502-507.

9. Inagaki $\mathrm{N}$, Kibata $\mathrm{K}$, Tamaki $\mathrm{T}$ et al.: Prognostic impact of the mean platelet volume/platelet count ratio in terms of survival in advanced non-small cell lung cancer. Lung Cancer 2014; 83: 97-101.

10. Yan M, Jurasz P: The role of platelets in the tumor microenvironment: from solid tumors to leukemia. BiochimBiophys Acta 2016; 1863: 392-400.

11. Taucher S, Salat A, Gnant M et al.; Austrian Breast and Colorectal Cancer Study Group: Impact of pretreatment thrombocytosis on survival in primary breast cancer. ThrombHaemost 2003; 89: 1098-1106.

12. Bath PM, Butterworth RJ: Platelet size: measurement, physiology and vascular disease. Blood Coagul Fibrinolysis 1996; 7: 157-161.

13. Leader A, Pereg D, Lishner M: Are platelet volume indices of clinical use? A multidisciplinary review. Ann Med 2012; 44: 805-816.

14. Gasparyan AY, Ayvazyan L, Mikhailidis DP et al.: Mean platelet volume: a link between thrombosis and inflammation? Curr Pharm Des 2011; 17: 47-58.

15. Kurt M, Onal IK, Sayilir AY et al.: The role of mean platelet volume in the diagnosis of hepatocellular carcinoma in patients with chronic liver disease. Hepatogastroenterology 2012; 59: 1580-1582.

16. Korniluk A, Koper-Lenkiewicz OM, Kamińska J et al.: Mean platelet volume (MPV): new perspectives for an old marker in the course and prognosis of inflammatory conditions. Mediators Inflamm 2019; 2019: 9213074.

17. Gu M, Zhai Z, Huang $\mathrm{L}$ et al.: Pre-treatment mean platelet volume associates with worse clinicopathologic features and prognosis of patients with invasive breast cancer. Breast Cancer 2016; 23: $752-760$.

18. Peinado $\mathrm{H}$, Zhang $\mathrm{H}$, Matei IR et al.: Pre-metastatic niches: organspecific homes for metastases. Nat Rev Cancer 2017; 17: 302-317.

19. Coffelt SB, Wellenstein MD, de Visser KE: Neutrophils in cancer: neutral no more. Nat Rev Cancer 2016; 16: 431-446.

20. Shaul ME, Fridlender ZG: Neutrophils as active regulators of the immune system in the tumor microenvironment. J Leukoc Biol 2017; 102: 343-349.

21. Geng Y, Shao Y, He W et al.: Prognostic role of tumor-infiltrating lymphocytes in lung cancer: a meta-analysis. Cell PhysiolBiochem 2015; 37: 1560-1571.

22. Mao $\mathrm{Y}, \mathrm{Qu} \mathrm{Q}$, Chen $\mathrm{X}$ et al.: The prognostic value of tumor-infiltrating lymphocytes in breast cancer: a systematic review and meta-analysis. PLoS One 2016; 11: e0152500.

23. Zheng X, Song X, Shao Y et al.: Prognostic role of tumor-infiltrating lymphocytes in gastric cancer: a meta-analysis. Oncotarget 2017; 8: 57386-57398. 